\title{
IMPROVEMENT OF THE METHOD OF ANALYSIS OF ASSET MANAGEMENT EFFICIENCY
}

\author{
Tetyana Kovalchuk ${ }^{1}$, Andriy Verhun ${ }^{2}$
}

\begin{abstract}
Assets are the key factor in the financial well-being of a business (the financial health of a business). Their composition and efficiency of use directly influence the end result of the enterprise's economic activity. Effective asset management can improve financial sustainability and increase the competitiveness of an enterprise. Therefore, in order to ensure financial sustainability and competitive advantage in the long run, it is necessary to address the challenge of continuous improvement in asset management. Financial analysis is an important tool for substantiating and controlling asset use decisions. As the turnover and return on assets depend to a large extent on the particularities of the industry and the conditions of business, the means of financial analysis must be tailored to specific situations. Therefore, the issues of improving the methods of financial analysis that would take into account the peculiarities of the activity of the enterprise are urgent. The purpose of this study is to substantiate a methodological approach to the analysis of asset utilization of Ukrainian bakeries. The methodological basis of this study is a system-based approach to solving the problems of analytical asset management. In generalizing the methodological principles of financial analysis of asset management effectiveness, techniques of abstract-logical method are used, namely: analysis and synthesis, induction and deduction, analogy and comparison. There were used methods of average and relative values, methods of modeling and factor analysis to make all the calculations; they were used to establish the relationship between the systems of financial indicators of asset efficiency. The calculation of the indicators of profitability and asset utilization in turnover was made according to the financial statements of Ukrainian bakeries. Asset management is aimed at increasing the efficiency of their use, the main generalization of which is the return on assets. The need to improve the methodology for analyzing the return on assets is due to the limited use of this indicator in the analysis of unprofitable enterprises on the one hand, and, on the other hand, to the need to take into account the specifics of the industry where the enterprise operates. Under conditions of loss, the asset return indicator distorted reflects the impact of its change factors, and industry features are reflected in different turnover rates of individual components of assets, and accordingly, in different intensity of their impact on profitability. The proposed approach is based on a multifactorial model that reflects the dependence of the asset on return to sales, non-current assets to sales, inventory to sales, accounts receivable to sales and cash assets to sales. The model determines the intensity of the impact on the return on assets of the partial indicators of the assets to sales. The calculations were made by a group of bakeries from different regions of Ukraine. As a criterion for assessing the effectiveness of asset management, it is proposed to use the average growth rate of partial indicators of the model of return on assets, which is determined taking into account the intensity of their impact. The specifics of the approach are more focused not on absolute indicators, but on indicators of dynamics, on the identification of trends. The advantage of the proposed indicator is the ease of interpretation, especially for the case of loss-making, which is peculiar for one third of the enterprises of the industry.
\end{abstract}

Key words: asset management, asset utilization efficiency, indicators of assets efficiency, return on assets, ratios of assets to sales.

\section{JEL Classification: G31, G32}

\section{Introduction}

In any enterprise, asset management is an important element that covers a wide range of tasks. They are represented in two directions: management of noncurrent and current assets.

\footnotetext{
Corresponding author:

${ }^{1}$ Yuriy Fedkovych Chernivtsi National University, Ukraine.

E-mail: t.kovalchuk@chnu.edu.ua

${ }^{2}$ Yuriy Fedkovych Chernivtsi National University, Ukraine.

E-mail: a.vergun@chnu.edu.ua
}

In the first direction, potential reserves for improving the efficiency of the use of non-current assets in the future period should be identified in the process of analysis and optimization of their total volume and composition should be carried out on this basis. The management 
of non-current assets is strategic. Therefore, the most important task here will be justified by the criterion of increasing the efficiency of use timely updating of production facilities. Although the management of non-current assets is also related to the current financial activities of the enterprise, the decisions regarding them relate to the long term.

The management of current assets is more related to the current activity of the company, so its effectiveness will be determined in the short term. It includes the effective management of the balance of goods and finished products, inventories of raw materials, accounts receivable, efficient use of cash and management of other current assets. Effective management of current assets can be argued if it ensures the continuity of the production process; accelerating the turnover of circulating assets and increasing their profitability; minimization of risks and costs associated with the formation and use of current assets, maintaining a sufficient level of liquidity of the enterprise. As the outward signs of such efficiency would serve a reduction in the duration of the operating cycle; improving the organization of logistics; acceleration of the shipment process of products and processing of settlement documents, acceleration of repayment of receivables, optimization of the balance of cash assets.

The success of these tasks depends to a large extent on the quality of information support for managerial decision-making. The decisions to be made must be based on reliable, validated information that truly reflects the objective reality, and the conclusions should be substantiated by accurate analytical calculations. In addition, an important management requirement is to provide a systematic approach when each object under study is viewed as a complex dynamic system that includes a number of elements, in some way related to each other and to the external environment; the study of each object should be carried out taking into account all internal and external relations, the interdependence of its individual elements. An important prerequisite is adherence to this principle when forming methodological support for the analysis of accounting data on the assets of the enterprise. The justification of the methodology for analyzing the efficiency of assets use of the enterprise is just the subject of this study.

\section{Current state of analysis of asset management effectiveness}

Management approaches to ensuring the effectiveness of current and non-current assets differ, it is explained by their different economic and material substance. However, methodological approaches to the analysis of individual components of assets have common features. Their effectiveness is determined by the ratio of the effect of use (sales) to the value of the assets themselves. In fact, efficiency can be achieved either by increasing the effect of the use of assets, or by reducing the period from receipt of the order to the shipment of finished goods and receiving cash from it, or by reducing the amount of attracted assets. In evaluating the efficiency of management's use of company assets many analysts compute total asset turnover and return on assets (Schwetje, Vaseghi, 2007).

Probably one of the most commonly used vital signs implemented in studying the financial health of a company is return on assets (ROA), that is viewed by many as an appropriate means of measuring management's efficiency in using company resources (Financial Accounting, 2012). It is calculated as net income divided by average total assets (Dewhurst, 2014). ROA shows how well or poorly management is employing the company's total assets to make a profit (the higher the return on assets for company, the more efficient management is utilizing the company's asset base) (Twineyo-Kamugisha, 2017). Furthermore, it indicates if it is worth using borrowings to finance assets (if the interest rate for the borrowings is lower than the return on total assets, the use of borrowings has proved worthwhile) (Schwetje, Vaseghi, 2007).

So a high return on assets indicates that the business has performed well by making profitable investments in the past, but it does not necessarily mean that you could buy the same assets today at their reported book values (Brealey, Myers \& Allen, 2011).

The informativeness of the ROA indicator is confirmed by the study of 544 failing and unfailing firms that illustrates that, as early as four years before they went bankrupt, the failing firms were earning a much lower return on assets (ROA) than firms that survived. (Beaver, McNichols \& Rhie, 2005).

If for the analysis of the efficiency of the use of total assets, including the efficiency of the use of noncurrent assets, the profitability indicator is generally accepted, the efficiency of the use of current assets is determined by other characteristics. In use, current assets are transformed from one settled state to another, thus, making a turnover. Therefore, the most important indicators of the efficiency of current assets use are turnover rates. They are calculated for the total working capital as a whole and for the various components of working capital separately.

In addition, it must be taken into account that some company's rivals may be pursuing power or scale-related targets (e.g., biggest turnover in the industry) that are frequently far removed from profitability targets, so it is very hard for groups pursuing profitability targets to grow in such conditions (Vernimmen, 2005). Therefore, in terms of comparative analysis, the use of turnover rates will be more preferential.

Turnover ratios are calculated by the ratio of sales revenue and the average of assets or their constituent elements. Turnover rates indicate management's efficiency at generating sales. Sales must occur before 
the profits can be earned from normal operations and if assets are not well used to create sales, the profits will probably never arise (Financial accounting, 2012).

The most general is total asset turnover. It is computed by the following formula (Financial accounting, 2012):

Total asset turnover $=$ sales revenue/average total assets

This figure provides an indicator of how productively capital has been utilized within the company by measuring how many times capital invested in the total assets has been turned over (Schwetje, Vaseghi, 2007). Normally, the higher this ratio is, the better, the more often capital has been turned over, the more efficient the assets have been utilized for the generation of sales (Schwetje, Vaseghi, 2007) but, as often the case with ratios, it is needed to look at industry norms (Dewhurst, 2014).

As already mentioned, turnover ratios are calculated for different components of assets.

Though turnover ratios are not as common with noncurrent assets as with current assets, however, if a company has large amounts reported for various fixed assets but fails to create high revenue balances, the ability of management to make good use of those assets has to be questioned (Financial accounting, 2012). So there is a necessity to calculate the noncurrent assets turnover, in particular, fixed assets turnover indicating the efficiency by which a company uses its property and equipment to generate sales revenues. These figures are calculated by taking net sales for a period and dividing it by the average net book value of the company's noncurrent assets (fixed assets).

The efficiency of the use of current assets is measured by such indicators as inventory turnover, receivables turnover, cash turnover. They represent how speedily a firm converts its inventories and accounts receivable into cash, how readily it pays its bills, and how efficiently it uses its assets to generate sales (Scov, 1994).

Inventory turnover shows how often a firm is turning over its inventory, shows the number of times that a firm's inventory balance was turned ("sold") during a year (Skousen, Walther, 2009) and similar to the asset turnover ratio, the inventory turnover is better when higher (Dewhurst, 2014). It is simply another way to measure the speed by which a company sells its inventory: the larger the turnover number, the faster inventory is selling (Financial accounting, 2012).

Equally important is to monitor the rate of collection because many businesses have substantial dollars tied up in receivables, and corporate liquidity can be adversely impacted if receivables are not actively managed to insure timely collection (Skousen, Walther, 2009). The age of receivables and the receivables turnover are the measures of speed or slowness of cash collections (Financial accounting, 2012). That number reveals how many times firm's receivables are converted to cash during the year (Skousen, Walther, 2009). So the higher the receivable turnover, the faster collections are being received.
Although turnover ratios are most common for the assets discussed above (inventory, receivables, fixed assets), any asset can be examined as a turnover ratio as long as the appropriate numerator is used in the calculation (Wahlen, Baginski, \& Bradshaw, 2011). Cash turnover ratio is computed by dividing sales by the average cash balance during the year (Amanda, 2019). It shows the efficiency with which cash is managed. Cash turnover is a measure of the efficiency of cash used by companies because the cash turnover rate describes the speed of return of cash invested in working capital (Amanda, 2019).

The higher cash turnover rate means the faster cash return goes to the company. Thus, cash will be used again to finance operational activities so as not to disrupt the company's financial condition (Haryanto, Sodikin \& Chaeriah, 2018).

\section{Formulation of the problem}

Obviously, no aggregate indicator or group of indicators can claim to be universal and objective in all situations. Its "objectivity" depends on the policy adopted, the specificities of the particular situation, etc. Therefore, the development of new indicators may be useful when it is necessary to take into account certain characteristics. The methodological approach being developed must be systemic, which means considering objects as complex systems that combine many elements of external and internal links. Comprehensive analysis involves a comprehensive study of the economy of the enterprise based on the study of the system of economic indicators, taking into account the factors that affect the results of the enterprise.

In applying this approach, the following should be noted. ROA indicator, while reflecting overall performance, does not quite reflect the performance of individual components of assets (their turnover) as it is significantlyinfluenced by the profit factor. Profit depends on both income and expenses. Therefore, if the average asset value was not large and the costs associated with earning income were significant, then asset efficiency by turnover ratio would be relatively higher than asset efficiency by profitability. That is, turnover figures will show the return on investment of assets (regardless of cost), and ROA will show the efficiency of all activities, which also takes into account the costs associated with the use of these assets. In particular, profitability depends on market conditions, such as prices and management's ability to adapt to changes. Therefore, in some periods, businesses may suffer losses not so much due to internal factors but the external ones. Analyzing the effectiveness of asset management during periods of impairment, if performed on the basis of profitability indicators, there may be some difficulties. This is due to the fact that it is difficult to distinguish between internal and external factors and, therefore, to mark negligible aspects of 
performance change. Therefore, it would be useful to use an asset management performance indicator that is as generalizable as the return on assets and, at the same time, takes into account internal aspects. In addition, it is obvious that this indicator should take into account the dynamics of the process of use (management) of assets.

Therefore, it is important to distinguish between the goals of using turnover and profitability. The first indicators show the return on invested capital in the form of sales, the second perform the return in the form of profit. The interpretation of these indicators may not coincide. This is due to the effects of other operating and non-operating factors for changing profits. Thus, the considerable income received per $1 \mathrm{UAH}$ of assets will be reflected in a considerable speed of turnover of assets, and the resulting small profit will be reflected in the low return on assets.

Profit is one of the most volatile indicators, because it is affected by both internal factors (that determine virtually all aspects of the enterprise) and external. In addition, the level of profitability, as well as the efficiency of use of assets depends on the status and characteristics of the industry in which the enterprise operates. Different industries have different structure of assets, different turnover of their components and therefore different influence of turnover indicators on profitability. An analysis of industry statistics shows that from 2013 to 2017, the proportion of unprofitable enterprises ranged from $27.5 \%$ to $37.7 \%$ (Table 1), that is, one third of enterprises suffered losses.

Table 1

Net profit (loss) of enterprises (\%)

\begin{tabular}{|c|c|c|}
\hline Year & $\begin{array}{c}\text { Proportion of enterprises } \\
\text { that made a profit in } \\
\text { the total number of } \\
\text { enterprises }\end{array}$ & $\begin{array}{c}\text { Proportion of enterprises } \\
\text { that received losses in } \\
\text { the total number of } \\
\text { enterprises }\end{array}$ \\
\hline 2013 & 62,3 & 37,7 \\
\hline 2014 & 62,4 & 37,6 \\
\hline 2015 & 72,6 & 27,4 \\
\hline 2016 & 72,5 & 27,5 \\
\hline 2017 & 71,4 & 28,6 \\
\hline
\end{tabular}

Source: The Report of the State Statistics Service of Ukraine, 2017

\section{Modelling of efficiency indicator}

The indicator discussed above - return on assets (ROA) - can be represented as such a factor model:

$$
R O A=\frac{P}{N A+I+A R+C A}
$$

where,

$\mathrm{P}$ - operating profit,

NA - non-current assets,

I - inventory,

AR - Accounts Receivable,

$\mathrm{CA}$ - cash assets.
By dividing the numerator and denominator by net sales $(S)$ we obtain the following dependence:

$$
R O A=\frac{\frac{P}{S}}{\frac{N A}{S}+\frac{I}{S}+\frac{A R}{S}+\frac{C A}{S}}
$$

In this model:

$\frac{\mathrm{P}}{\mathrm{S}}-$ return on sales (ROS),

$\frac{\mathrm{NA}}{\mathrm{S}}-$ non-current assets to sales ratio (NAS),

$\frac{\mathrm{I}}{\mathrm{S}}$ - inventory to sales ratio (IS),

$\frac{\mathrm{AR}}{\mathrm{S}}$ - accounts receivable to sales ratio (ARS),

$\frac{\mathrm{C}}{\mathrm{S}}$ - cash assets to sales ratio (CS).

The indicators of NAS, IS, ARS, CS are inverted to the above discussed turnover rates (non-current assets turnover, inventory turnover, receivables turnover, cash turnover ratio). They reflect another aspect of asset management effectiveness. If turnover figures show a return on invested capital, then assets to sales indicators show the "cost" of assets to generate returns in the form of income. Effective asset management is characterized by an increase in turnover rates, but a decrease in congestion rates.

Given the above designations, this model can be represented as:

$$
R O A=\frac{R O S}{N A S+I S+A R S+C S}
$$

It shows that the return on assets depends on the profitability of sales and methods of managing assets, their structure and the degree of attraction to turnover. These indicators are largely determined by the characteristics of the industry which the enterprise belongs to. As the model implies, an increase in return on sales (ROS) and a decrease of indicators: noncurrent assets to sales (NAS), inventory to sales (IS), accounts receivable to sales (ARS) and cash assets to sales (CS) will help to increase return on assets (ROA), that is, increase asset utilization efficiency. However, it is necessary to consider the peculiarities of interpretation of this model for the case of loss. In the case of unprofitableness, a decrease in the denominator of the formula (assets to sales by type) will indicate an increase in the unprofitableness, i.e. a decrease in efficiency. And this contradicts the previous interpretation.

Thus, the return on assets is of limited use in the analysis of unprofitable enterprises, because the change in the focus of the function loses the economic content of dependency. The indicator gives a distorted idea of the structure of influence. However, it is possible to obtain an objective assessment of the asset's performance on the basis of this model, including in the case of impairment, if we consider the change in factor 
indicators dynamically. In this approach, it is suggested to use the average rate of growth of the variable return on assets, which is determined on the basis of the individual rate of growth of each factor. The latter are adjusted by appropriate weights.

The survey used information on the performance of 23 bakeries located in different regions of Ukraine.

In the first stage, by each enterprise was determined the impact of return on sales $(\triangle \mathrm{ROA}(\mathrm{ROS}))$, noncurrent assets to sales $(\triangle \mathrm{ROA}(\mathrm{NAS}))$, inventory to sales $(\triangle \mathrm{ROA}(\mathrm{IS}))$, accounts receivable to sales $(\triangle \mathrm{ROA}(\mathrm{ARS}))$ and cash assets to sales $(\triangle \mathrm{ROA}(\mathrm{CS}))$ on the indicator return on assets (ROA).

Objective evaluation uses an integrated method that allows to measure impact without setting a strict order. According to this method, the impact is determined by the formulas:

$$
\begin{aligned}
& \Delta R O A(R O S)=\frac{\Delta R O S}{\Delta N A S+\Delta I S+\triangle A R S+\Delta C S} \times \\
& \times \ln \left|\frac{N A S^{1}+I S^{1}+A R S^{1}+C S^{1}}{N A S^{0}+I S^{0}+A R S^{0}+C S^{0}}\right| \\
& \Delta R O A(F A S)=\frac{\Delta R O A \quad \Delta R O A(R O S)}{\Delta N A S+\Delta I S+\Delta A R S+\Delta C S} \times \Delta F A S \\
& \triangle R O A(I S)=\frac{\Delta R O A \quad \Delta R O A(R O S)}{\Delta N A S+\Delta I S+\triangle A R S+\Delta C S} \times \Delta I S \\
& \triangle R O A(A R S)=\frac{\Delta R O A \quad \Delta R O A(R O S)}{\Delta N A S+\Delta I S+\triangle A R S+\Delta C S} \times \triangle A R S
\end{aligned}
$$

$$
\Delta R O A(C S)=\frac{\Delta R O A \quad \Delta R O A(R O S)}{\Delta N A S+\Delta I S+\Delta A R S+\Delta C S} \times \Delta C S
$$

The second stage. In determining the significance of each factor, it is taken as a basis that it is reflected in the magnitude of its impact on the rate of return on assets. The calculation is made by the formula:

$$
\lambda_{x_{i}}=\frac{\left|\Delta R O A\left(x_{i}\right)\right|}{\sum_{i=1}^{n}\left|\Delta R O A\left(x_{i}\right)\right|} \times n
$$

where,

$\lambda_{x i}$ - weighting coefficient,

$x_{i}$ - factor of influence,

$n$ - number of factors,

$\triangle R O A\left(x_{i}\right)$ - the impact of the factor on the return on assets.

The results of the calculation of the weight coefficients for the group of studied enterprises are presented in table 2 .

At the last stage, a generic indicator of asset efficiency is formed:

$$
\bar{G}=\frac{1}{n} \sum_{i=1}^{n} \lambda_{x_{i}} \times G_{x_{i}}
$$

\begin{tabular}{|c|c|c|c|c|}
\hline Enterprises & $\lambda_{\text {NAS }}$ & $\lambda_{\mathrm{IS}}$ & $\lambda_{\mathrm{ARS}}$ & $\lambda_{\mathrm{CS}}$ \\
\hline Chernivtsi bread-baking complex & 1,4838 & 1,2250 & 1,2001 & 0,0911 \\
\hline Drohobych bread-baking complex & 2,4809 & 1,1642 & 0,2282 & 0,1267 \\
\hline Stryi bread-baking complex & 2,5088 & 0,5567 & 0,8597 & 0,0749 \\
\hline Vasylivka bread-baking complex & 3,8437 & 0,0435 & 0,0145 & 0,0983 \\
\hline Shostka bread-baking complex & 1,0622 & 1,7990 & 0,9441 & 0,1947 \\
\hline Konotop bread-baking complex & 1,6073 & 1,5789 & 0,4865 & 0,3273 \\
\hline Nikopol bread-baking complex & 1,8399 & 0,1296 & 1,9948 & 0,0357 \\
\hline Kryvyi Rih bread-baking complex №1 & 1,4497 & 1,2452 & 1,2833 & 0,0219 \\
\hline Cherkasy bread-baking complex & 2,6515 & 0,9129 & 0,4303 & 0,0054 \\
\hline Dnipropetrovsk bread-baking complex №9 & 1,3503 & 0,9179 & 1,5913 & 0,1405 \\
\hline PJSC "Novovolynsk bread-baking complex" & 1,6100 & 0,1961 & 0,9269 & 1,2670 \\
\hline PJSC "Olevsk bread-baking complex" & 2,2330 & 0,8008 & 0,4328 & 0,5334 \\
\hline PJSC "Khlibnyy kolos" & 0,9257 & 1,3272 & 1,7424 & 0,0046 \\
\hline PJSC "Slavuta bread-baking complex" & 1,4601 & 1,7490 & 0,3487 & 0,4422 \\
\hline PJSC "Izyaslav bread-baking complex" & 0,5741 & 0,8126 & 1,6937 & 0,9197 \\
\hline PJSC $\ll$ Chortkiv bread-baking complex» & 2,3581 & 0,4684 & 1,0353 & 0,1382 \\
\hline Open Joint Stock Market Entity "Berezhany bread-baking complex" & 3,3667 & 0,3695 & 0,1150 & 0,1488 \\
\hline PJSC "Lyubotyn bread-baking complex" & 1,3383 & 1,9037 & 0,7307 & 0,0273 \\
\hline PJSC "Korosten bread-baking complex" & 0,9835 & 1,8969 & 1,0048 & 0,1147 \\
\hline PJSC "Novograd-Volynskyy bread-baking complex" & 2,4551 & 0,5333 & 0,1833 & 0,8282 \\
\hline PJSC "Ovruch bread-baking complex" & 1,8205 & 1,2759 & 0,7664 & 0,1371 \\
\hline PJSC "Dzerzhynskbread-baking complex" "Toretsk bread-baking complex" & 1,2862 & 1,7096 & 0,7946 & 0,2095 \\
\hline PJSC "Kryvorizhkhlib" & 0,7770 & 1,2468 & 1,8899 & 0,0862 \\
\hline Average by group of enterprises & 1,8029 & 1,0375 & 0,8999 & 0,2597 \\
\hline
\end{tabular}

where,

$G_{x i}$ - the rate of growth of the respective asset turnover rate in circulation.

or:

$$
\bar{G}=\frac{1}{4}\left(1,8029 \times G_{\mathrm{FAS}}+1,0375 \times G_{\mathrm{IS}}+0,8999 \times G_{\mathrm{ARS}}+0,2597 \times G_{\mathrm{CS}}\right)
$$

Table 2

Weighting coefficients by group of baking enterprises 
The value of this indicator should be less than 1 . This will mean that the efficiency of use of assets during the period under review has increased.

\section{Conclusions}

Existing methods of analyzing the effectiveness of the use of assets in most of them involve the use of a system of indicators, including indicators of return on assets, asset turnover, and duration of asset turnover.

An analysis of these indicators shows that they may not fully reflect the asset management performance of unprofitable enterprises and require such an interpretation of the results of the calculations, which would take into account the specifics of the industry in which the enterprise operates.

On the basis of multifactor model of return on assets the indicator of efficiency of assets use of the enterprise is developed. It represents the average rate of growth of non-current assets to sales, inventory to sales, accounts receivable to sales and cash assets to sales, adjusted for the individual importance of each according to the intensity of their impact on the indicator of return on assets. This indicator reflects the peculiarities of the assets turnover of the bakery industry in Ukraine and is convenient for analyzing the use of assets of both profitable and unprofitable enterprises.

The developed methodological approach to the analysis of asset management integrates traditional performance indicators into the system and allows considering them in the dynamics and taking into account the weight of the impact of the performance indicators of individual components of assets on the profitability indicator. It can be applied to different industries, taking into account the features of asset turnover and the level of profitability.

The proposed metric provides an understandable criterion for generalizing the dynamics of asset performance indicators by type. A value of less than 1 indicates an increase in efficiency in the study period. The decision-maker thus receives a tool for evaluating the effectiveness of decision-making related to asset management, taking into account industry specificities.

\section{References:}

Amanda, R. I. (2019). The Impact of Cash Turnover, Receivable Turnover, Inventory Turnover, Current Ratio and Debt to Equity Ratio on Profitability. Journal of research in management, 2(2), 14-22. Retrieved from: https://www.researchgate.net/publication/334320658_The_Impact_Of_Cash_Turnover_Receivable_ Turnover_Inventory_Turnover_Current_Ratio_And_Debt_To_Equity_Ratio_On_Profitability

Beaver, W. H., McNichols, M. F., \& Rhie, J. W. (2005). Have Financial Statements Become Less Informative? Evidence from the Ability of Financial Ratios to Predict Bankruptcy. Review of Accounting Studies, 10(1), 93-122.

Brealey, A. R., Myers, S.C. \& Allen, F. (2011). Principles of corporate finance. New York, McGraw-Hill/Irwin, 969 p. Dewhurst, J. A. (2014). An Introduction to Business and Business Planning - Bookboon.com. Retrieved from: https://bookboon.com/en/an-introduction-to-business-and-business-planning-ebook

Financial Accounting (2012). Saylor Academy, 746 p.

Haryanto, Sodikin, A., \& Chaeriah, E. S. (2018). Effect of Turnover of Cash, Receivables Turnover and Inventory Turnover on Return on Assets. Journal of Arts Humanities and Social Sciences Studies, 3(1), 62-81.

Schwetje, G., \& Vaseghi, S. (2007). The Business Plan How to Win Your Investors' Confidence. New York, Springer Berlin Heidelberg New York, 180 p.

Skousen, C. J., \& Walther, L. M. (2009). Current Assets - Bookboon.com, p. 97. Retrieved from: https://bookboon.com/ en/current-assets-ebook

Skov, N. A. (1994). Finance and Management. Warczawa, Pret, p. 247.

The official site Derzhavna Sluzhba Statystyky (2017). Activities of enterprises. Retrieved from: http://www.ukrstat.gov.ua/ druk/publicat/kat_u/publ9_u.htm (in Ukrainian)

Twineyo-Kamugisha, E. R. (2017). The Basics of Business Management. Vol I.: Leadership, Financial Management and Economics - bookboon.com, 283 p. Retrieved from: https://bookboon.com/en/the-basics-of-businessmanagement-vol-i-ebook

Vernimmen, P. (2005). Corporate Finance Theory and Practice. Chichester, John Wiley \& Sons Ltd, p. 1032.

Wahlen, J. M., Baginski, S. P., \& Bradshaw, M. (2011). Financial Reporting, Financial Statement Analysis and Valuation: A Strategic Perspective. Mason, Ohio, Thomson, p. 1261. 